\title{
O TZV. PUČKOJ ETIMOLOGIJI (TJ. MOTIVACIJI)
}

$\mathrm{Na}$ izboru od gotovo 90 primjera ovaj rad ilustrira navedenu jezičnu pojavu, na četiri glavne razine jezične analize (fonetskoj, morfosintaktičkoj, tvorbenoj, semantičkoj) i na temelju kako usmenih tako i pisanih izvora, neobrazovanih, poluobrazovanih i obrazovanih slojeva.

1. Ovim se kratkim prilogom pridružujemo svečanom broju u čast uvaženoga Slavljenika, profesora Janeza Orešnika. Tema je našega priloga toliko poznata i obrađivana da vjerujemo kako ne treba nikakvih objašnjenja; zato upućujemo samo na knjigu Alberta Zambonija L'etimologia (v. literaturu), koja u posebnom poglavlju o pučkoj etimologiji (str. 101-112) upozorava da to nije dio etimološke znanosti, nego je sama po sebi jezična pojava. ${ }^{1}$

2. U ovom će radu biti zastupljene sve jezične razine, od fonetske, preko morfosintaktičke i tvorbene, do semantičke; izvori ce biti kako pisani tekstovi tako i usmeni primjeri, i to od neobrazovanih, poluobrazovanih do potpuno obrazovanih govornika, a po pitanju namjere odn. svrhe (dakle, s pragmatičkoga gledišta), naši primjeri su nesvjesni (većina) ili svjesni (šale, igre riječi).Većina je primjera iz hrvatskog jezika, tek neki su iz slovenskoga, talijanskoga i njemačkoga (svega jedan). Napominjemo da je striktna podjela na razine vrlo delikatna, često upravo nemoguća, jer primjeri mogu pripadati i više nego jednoj od njih. ${ }^{2}$

\section{Fonetska razina}

3. U jednoj zagrebačkoj prodavaonici voća, koje već odavno nema, za jabuke vrste belle fleur jednoga se dana pojavila cedulja s natpisom bijeli fler, jer je francusko belle, izgovoreno [bel], bilo shvaćeno kao pridjev „bijeli“ i zato hiperkorektno ijekavizirano. Kasnije je netko vjerojatno upozorio osoblje na pravo značenje naziva belle fleur, jer se pojavila nova cedulja s natpisom ljepocvjetka, dakle $\mathrm{s}$ potpunim prijevodom.

4. Koncem lipnja i početkom srpnja 1969. g. potpisani je autor sudjelovao u radu prvoga znanstvenoga skupa i tečaja surselvanskoga retoromanskoga govora, pa

\footnotetext{
${ }^{1}$ L'etimologia, str. 104: „mentre l'etimologia è un' i n t e r p r e t a z i o n e [spac. A.Z.] di fatti linguistici, l'etimologia popolare è un fatto linguistico essa stessa".

${ }^{2}$ Zamboni (op.cit., str. 110-111) razlikuje četiri mogućnosti, prema tome je li zahvaćen oblik, značenje, oboje ili ni jedno ni drugo, ali to nije ista kategorija kao naše razine, pa se na to nećemo više osvrtati.
} 
je od ministarstva kojem se obratio za novčanu pomoć dobio odgovor u kojem je stajalo retroromanski, a isti smo oblik našli i kasnije u raznim drugim publikacijama. Protivno onom što je inače česta pojava u jeziku, tj. disimilacija upravo suglasnika / $r$ / (v. reflekse lat. PEREGRINUS u romanskim jezicima; MENETRIS za MERETRIX u Appendix Probi; RARU > tal. rado i deseci drugih), ovdje je / $r$ / umetnuto, pa umjesto dvočlanoga niza / $\mathrm{r}-\mathrm{r} /$ imamo tročlani / $r-r-r /$. Više je objašnjenja moguće: hiperkorektno umetanje /r/ (s pretpostavkom da je reto- disimilirano retro- ); protivno tomu - paradoksalno, ali također moguće ${ }^{3}$ - neko asimilacijsko „protezanje“ konsonanta /r/ na sva tri sloga; najvjerojatnije, ipak, čini nam se semantičko tumačenje, tj. da je taj govor nešto staro, relikt iz davnih dana, pa retro- ima značenje kao u retroaktivno (u administrativno-pravnoj terminologiji), retrogradno i sl.

5. U broju od 17. siječnja 1988. zagrebačkoga dnevnika Vjesnik objavljen je napis o tartufima (pod naslovom Tajna zlatne pljesnivice), u kojem se spominje i gljiva suprofit, koja raste na starom suhom drvu. Držimo da to nije banalna tiskarska pogreška, jer je jasno da se radi o saprofitu, tj. neke vrste parazitu, ${ }^{4}$ pa je netko shvatio da je to nešto što "dijeli profit s nečim drugim" $i$, na temelju parova saradnja - suradnja, savremen - suvremen i dr., mislio da i saprofit treba „kroatizirati“" u suprofit. Taj primjer spada i na tvorbenu razinu.

\section{Morfosintaktička razina}

6. Pred više od 30 godina osvanuo je u slovenskom listu TT osvrt na anketu koju su novinari provodili pitajući djevojke na ulicama bi li obukle topless (što je tada bilo još $i n$ ). Jednu od djevojaka pratio je momak, koji je novinaru odbrusio Izgini, sicer ti priskrbim en top les v glavo! („Gubi se, ili ćeš dobiti jedno tupo drvo u glavu!"). Motivacija je jasna, a u isto vrijeme i odlična igra riječi.

7. Nekako za vrijeme II. svj. rata ili neposredno poslije njega autorova punica (srednje obrazovana) u Dakovu imala je kućnu pomoćnicu, koja je dakako bila neobrazovana i pomalo retardirana. Jednom joj je punica rekla neka ekspedira mačke iz kuhinje, i malo poslije djevojka joj je došla reći da je eksplodirala mačke. Ovdje razabiramo dva faktora: izvanjezični ("naglo, energično istjerati mačke") i jezični (glagol eksplodirati svakako je češći i u širokim slojevima poznatiji nego ekspedirati).

8. U feljtonu o Bunjevcima, pred cca 30 godina u Vjesniku, dva puta je kao genitiv množine imenice martoloz umjesto martoloza stajalo martologa, posve jasno prema filolozi -filologa, etnolozi - etnologa i dr., premda se dakako ne radi ni o kakvoj znanosti nego o nekadašnjom rodu turske vojske. ${ }^{5}$

\footnotetext{
3 Potpisani je autor poznavao vrhunskoga znanstvenika koji je umjesto kompetentan često znao reći kompententan, protežući tako nazalni završetak na sva četiri sloga.

4 AG, s.v. saprofiti: "heterotrofne biljke (bakterije, gljive); hrane se neživom organskom hranom; od grč. saprós 'truo'+FIT(I)"; s.v. fit itd. "od grč. phyton 'biljka'".

5 AG, s.v. martòloz: "plaćeni vojnik u pograničnim vojnim formacijama Osmanskog carstva na Balkanu (15. do 19. st.)".
} 
9. U morfološkom je smislu vrlo zanimljiv sljedeći primjer. U križaljkama često se za pojam "ubojica iz zasjede" naiđe na riječ asas. Ishodište je srednjevjekovno hašašin, prvotno "uživalac hašiša", kasnije oznaka za islamske ekstremiste i protivnike križara. ${ }^{6} \mathrm{U}$ životu te riječi mogu se utvrditi tri faze: 1) sr.lat. odnosno tal. assassino prihvaćeno je i adaptirano kao asasin, po uzoru na castellano - kastelan, birichino - reg. berekin itd.; 2) prema jednini Bugarin množ. Bugari, pa Riječanin - Riječani itd., od asasin stvorena je množina asasi; napokon, 3) od asasi, po modelu Sasi - Sas, Rusi - Rus itd. izvedena je "nova", analogijska jednina asas. Sve se svodi na dobro poznatu težnju prema "pravilnosti", tj. predvidivosti:

$$
\mathrm{x}: \mathrm{y}=\mathrm{x} 1: \mathrm{y} 1 \text {. }
$$

10. Napokon, dva primjera morfološke motivacije, oba od slučajnih suputnika na relaciji Split - Zagreb odnosno Rim - Zagreb. Prvi je primjer deformacija imena Stuttgart u Štutgrad, u jednoj skupini putnika vrlo skromna obrazovanja, tipičnih gastarbajtera; motivacija koja je brez problema. Drugi je primjer kompliciraniji i zanimljiviji. Potpisani autor je jednom putovao iz Rima $u$ Zagreb, a supotnica mu je bila jedna starija žena, sa samo osnovnim (možda čak nepotpunim) obrazovanjem, koju je autor odavna poznavao i koja talijanski nije znala. Na pitanje kako se snalazi u Italiji bez znanja jezika, što kaže kondukteru, pasoškoj kontroli itd., odgovorila je da jednostavno kaže ì turist jugoslàv Sicilija - Zagàberje. U njezinim je ustima, dakle, tal. naziv Zagabria postao Zagàberje, po uzoru na naše toponime kao G(r)aberje, Začretje, Zabukovje i sl. Motivacija i kao posljedica stranoga imena ovdje je i morfološka i fonetska, a dodiruje i tvorbenu razinu.

\section{Tvorbena razina}

11. U Bologni, ljeti 1970, jedno je osvježavajuće piće bilo reklamirano kao trissetante; dakle je prefiks dis-, inače privativan (usp. slov. odžejati "(u)gasiti žeđu"), shvaćen kao numerički i zamijenjen s isto tako numeričkim tri- (npr. tricolore, tripartito), naravno u reklamne svrhe, dakle svjesno.

12. U igrokazu Zi muorta Sa Batalita "Umrla je kuma Batalita" poznatog rovinjskog pisca Giusta Curta, jedna od osoba, izjelica i sladokusac, ovako komentira karmine: Ben, cume bevanda i nun sa lamantemo, ma cume magneifica... sa pudiva pioûn unurà l'ultima vuluntà da la dafoûnta $\mathrm{Pa}$, što se tiče pića, ne možemo se potužiti, ali po pitanju jela ... mogla se više poštovati posljednja volja pokojnice" (str. 71). Tu je imenica magneîfica, stvorena po modelu bonifica (<bonificare), rettifica (<rettificare) i brojnih drugih dovedena u vezu $\mathrm{s}$ glagolom magnà (tal. mangiare) ,jesti“, dok je stvarno samo adaptacija latinskoga magnificat $i$ inače poznata u jeziku. ${ }^{7}$

\footnotetext{
6 AG, s.v. asàsini [sic, akcent]: "pripadnici ekstremne islamske sekte, zasnovane na strogoj organizaciji i slijepoj poslušnosti poglavaru sekte (11. - 13. st.); glavni cilj bio je borba protiv križara; sr. lat. assassini < haššašinn ' 'uživalac hašiša' ".

7 Pellizzer s.v. magneîfica: "(scherz.) Cibo, vitto, alloggio, in genere tutto quello che attiene al mangiare.Traduzione irreverente del Magnificat dedicato alla Vergine. Chiogg. magnifica, mangiare.« Analogno i Doria, s.v. magnifica.
} 
13. U epizodi od 15. travnja 1989. austrijske zabavne serije Die liebe Familie otac obitelji, ugleđni gradžanin, Franz Lafitte najavljuje da će otići na dva tjedna odmora na jezero Attersee i pri tom upotrebljava infinitiv [sich] efrauzipieren. Taj glagol (koji je nemoguće prevesti) stvoren je ad hoc, igrom riječi, prema emanzipieren, na temelju šaljive motivacije man = Mann "muž, suprug" - frau = Frau, „žena, supruga“.

14. Dražestan primjer motivacije našli smo u Književnim listima (Ljubljana) od 22. 12. 1988, u članku Franca Žagara Ali šola sme biti šala (igriv pouk)? (to je zapravo prikaz dviju knjiga Berte Golob o jeziku s djecom u školi). Evo toga primjera:

Mateja (dijete, nosi medu): Medo je bolan, je tukaj bolanta.

Liječnik: Ambulanta.

Mateja: Zakaj ambulanta, saj medo ni ambulan ampak bolan.

Dijete je dakle povezalo, tj. motiviralo segment -bulan- $\mathrm{s}$ pridjevom bolan „bolestan“.

15. Pred više od 30 godina $u$ jednom planinarskom domu na Sljemenu (tj. na Medvednici ili Zagrebačkoj gori) radila je jedna vrlo simpatična konobarica, sa srednjom ugostiteljskom školom u kojoj je jedan od predmeta bio francuski jezik. Jednom je u razgovoru rekla da joj je najteže u francuskom bilo podmuklo e, misleći očito na tzv. muklo e (e muet). Motivacija može ovdje biti posve formalna (muklo - podmuklo), ali je vjerojatnije da je uvjetovana sadržajno, jer su za muklo e i izgovor i distribucija prilično komplicirani, „podmukli“.

16. Karakterističan primjer za upravo grubo nasilje nad suvremenim hrvatskim jezikom u tisku našli smo u Vjesniku od 3. srpnja 1997, gdje se u napisu o roniocima dva puta spominje obukacijski centar u Lošinju.Radi se naravno o kontaminaciji obuka i edukacijski, pa iako ne postoji pogodna izvedenica od obuka, ipak je obukacijski i pretpostavljeno *obukacija posve strano i neprihvatljivo u hrvatskoj tvorbi riječi.

\section{Semantička razina}

Ovdje se radi o značenju, promjena oblikâ nema.

17. U jednoj (ako se dobro sjećamo Reisingerovoj) karikaturi na jednom obronku planine stoji Pero s malim Štefekom, dok sa suprotnoga obronka jedan planinar pada u dubinu.Pero kaže malomu: Vidi, sine, goropadna čovjeka. Pridjev goropadan ovdje je dakle u doslovnom značenju obaju sastavnih dijelova umjesto uobičajenoga leksikaliziranog značenja. I to je dakako svjesna motivacija.

18. U Vjesniku od 22. kolovoza 1992, u vezi s padom (okupacijom) Drniša, spominje se pravi krešendo među nekim političarima. Premda uobičajeno značenje (dakako, u prenesenom smislu) ne bi bilo nemoguće, mislimo ipak da je ovdje krešendo motivirano hrvatskom riječju kreševo „sukob, borba“. Ne možemo međutim kazati je li ta motivacija nesvjesna ili je svjesna igra riječi. 
Završavamo trima primjerima motivacije glagola lažirati hrvatskom imenicom laž, iako s njom nema nikakve veze. ${ }^{8}$

19. Vjesnik od 19. travnja 1998. donosi vijest o osnutku ogranka društva „Josip Broz Tito" gdje se kaže da mladi ne znaju tko je bio Tito ni što je bila NOB, jer: Povijest je lažirana.

20. Isti list, u broju od 28. kolovoza 2003, pod naslovom Neke županije lažirale liste škola s otežanim uvjetima rada, piše (izvučeni tekst) da se traži od Predsjednika Vlade da intervenira i smijeni one koji su davali lažne podatke.

21. U Vjesniku od 7. listopada 2003. čitamo: Ubio se novinar Sky Newsa koji je lažirao izvještaj iz iračkog rata (u tekstu se spominju lažirana izvješća, namještena za novinarovu kameru).

\section{Pregled kriterija klasifikacije}

(u zagradama brojevi primjerâ)

22. Budući da smo razine jezične analize uzeli kao temeljni kriterij razvrstavanja primjera, ovdje ćemo promotriti i druge uobičajene sociolingvističke kriterije.

22.1. Jezici kojima pripadaju primjeri:

- slovenski: 6,14

- talijanski: 11,12 ;

- njemački: 13;

- hrvatski: 1-5, 7-10, 15-20.

22.2. Stupanj obrazovanja:

- neobrazovani: $3,7,10,14$

- poluobrazovani: $4(?), 9,12,15,16,19$;

- obrazovani: $5,6,8(?), 11,13,20(?)$.

22.3. Spol, uzrast:

- ženski: $7,10,15$;

- dijete: 14

- muški/neopredijeljeni: svi ostali.

22.4. Izvori:

- govoreni (dijalog): 6, 7, 10, 13, 14, 15;

- pisani (štampani itd.): 3, 4, 5, 8, 9, 10, 11, 12, 16, 18, 19, 20.

22.5. Pragmatički pogled (svrha, namjera):

- svjesna upotreba: $6,11,12(?), 13,17,18(?)$;

- posebno: igre riječi: $6,3,17$;

- nesvjesna upotreba: ostali primjeri.

${ }^{8} \mathrm{AG}$, s.v. lažirati: u sportskom žargonu »namjerno pretrpjeti poraz u dogovoru s protivnikom ili trećim kojemu to odgovara; od franc. lâcher 'prepustiti' ». 


\section{Literatura}

AG: V. Anić - I. Goldstein, Rječnik stranih riječi, Zagreb 2000.

BALBI - MosCARDA Budić: M. Balbi - M. Moscarda Budić: Vocabolario del dialetto di Gallesano d'Istria, RovignoTrieste, 2003.

CERneCCA: D. Cernecca, Dizionario del dialetto di Valle d'Tstria, Rovigno-Trieste 1986.

CuRTo: G. Curto, Zi muorta Sa Batalita, u: Istria Nobilissima, Trieste, 1973, str. 63-78.

Dalla Zonca: G.A. Dalla Zonca, Vocabolario dignanese-italiano, a cura di Miho Debeljuh, Trieste 1978.

Dorla: M. Doria, Grande dizionario del dialetto triestino storico etimologico fraseologico, Trieste 1987.

MANZINI-RocchI: G. Manzini - L. Rocchi, Dizionario storico fraseologico etimologico del dialetto di Capodistria, Trieste-Rovigno, 1995.

Pellizzer: A. e G. Pellizzer, Vocabolario del dialetto di Rovigno d'Istria I-II, Trieste-Rovigno 1992.

ZAMBONI: A. Zamboni, L'etimologia, Bologna 1976.

\section{Povzetek \\ MOTIVACIJA V JEZIKU (LJUDSKA ETIMOLOGIJA)}

Prispevek obravnava dvajset primerov motivacije („ljudske etimologije“) v hrvaščini, slovenščini, italijanščini in nemščini, in sicer na štirih glavnih ravneh jezikovne analize (fonetika, morfosintaksa, besedotvorje, semantika) in treh stopnjah kulture (nižji, srednji, višji). 